\title{
Acknowledgments
}

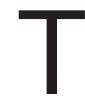

HIS BOOK WAS WRITTEN WITH THE SUPPORT OF MANY GENerous contributors who provided their encouragement, feedback, research assistance, and financial support over the years. I am first off indebted to my wonderful parents Pam and Walt Early for all the support they have provided me. I would also like to thank my wife Pamela Early for her depthless patience, love, and encouragement over the many years of work that went into this book.

I would especially like to thank all the institutions that made this book possible through their financial support. I would first like to thank the Center for International Trade and Security at The University of Georgia, which provided me with the initial support for this project. A portion of this project was also researched while I was a Research Fellow with the Belfer Center for Science and International Affairs at Harvard University's John F. Kennedy School of Government from 2008 through 2009. The Belfer Center provided a wonderful intellectual environment for developing a number of the core ideas of this project. I would also like to thank the Dubai School of Government, which hosted me as a Visiting Scholar in 2009, where I gained a lot of firsthand insights into the book's subject matter. My authorship of this book was chiefly made possible by a generous grant from the Smith Richardson Foundation as part of its International Security \& Foreign Policy Junior Faculty Research Grant Program. I am very grateful to the Smith Richardson Foundation for granting me the time and resources I needed for this project. I would 
not have been able to write this book without the Foundation's support. Lastly, I would like to thank the Rockefeller College of Public Affairs and Policy at the University at Albany, SUNY, for funding my book workshop in the summer of 2013.

I am indebted to a number of individuals who provided me with their feedback on this project as well. At the University of Georgia, I would like to thank Jeffrey Berejikian, Douglas Stinnett, Jaroslav Tir, and Brock Tessman. Special thanks are also due to Gary Bertsch, who opened the door for me to learn about economic statecraft. I would also like to especially thank Matthew Fuhrmann, who has provided me with great advice and feedback throughout this book project. In addition, I would like to thank Navin Bapat, Amanda Carroll, Johannes Karreth, Kristine Kilanski, Rey Koslowski, Cale Horne, Quan Li, Michael Mood, and Patty Strach for the feedback they provided on various aspects of this project. I would also like to sincerely thank Victor Asal, A. Cooper Drury, Sally Friedman, Katja Kleinberg, David Lektzian, Julie Novkov, and David Rousseau for the incredibly useful feedback they provided at my book workshop. Last but not least, I would like to thank all of the current and former government officials and members of the sanctions policy community who provided background and feedback for me on my project. One of the reasons for greater optimism regarding the use of economic sanctions is that there are so many intelligent, motivated individuals in the policy world committed to making sanctions policies more effective.

Finally, I would like to acknowledge the wonderful support I have received from my research assistants in the Department of Political Science at the University at Albany. I would like to thank Nolan Fahrenkopf and Keon Weigold for their excellent editorial support and the supporting research they provided me with during this project. I would like to provide especial thanks, though, to Amira Jadoon for the exceptional assistance she provided in researching the case studies conducted as part of this project. Amira was also instrumental in supporting my efforts to incorporate an explanation of aid-based sanctions busting into my study. I am very grateful to have had her support on this project and all the positive contributions she has made to it. 


\section{BUSTED SANCTIONS}


